Zsófia KENESEY

Márta NAGYNÉ SASVÁRI

László PATAKI

Rita Anna AMBRUS

\title{
3.2. NEW WAYS OF EUROPEAN BANKING REGULATION AND DEPOSIT INSURANCE
}

\begin{abstract}
Summary
The crisis in 2008 resulted in significant changes in banking regulation just as in all fields of economy. The business activities of the greatest banks encompass the whole world. It is not easy to follow these complex connections and to observe the regulations. The infectious effect of the systematically important financial institutions (SIFIs) may endanger the whole bank system. Such banks are able to drag down even the economies of the countries in which they operate. This is why it is important to apply more stringent regulations to banks than to other businesses. The Basel rules, the latest EU regulations and the bank union itself have been created also for this purpose. In our study, we shall present changes in the field of the EU bank regulation, which tends to become rule-based rather than risk-based. We discuss how the latest regulations shape the operation of the sector. Naturally, there are opponents to bank regulation. The so-called free banking means, in fact, that the regulation of the banks is based on the market, the managers are aware of the risks they take, and therefore they are able to react to the economic shocks in due time, and ultimately, they take it for granted when they are bailed out by the central bank which supports them. Nevertheless, bank regulation has been continuously developing and supplemented with new elements in the recent years, and experiences show that such a regulation is really necessary.
\end{abstract}

Keywords: banking regulation, SIFIs, bank union, free banking

\section{Importance of Banking Regulation in the European Union}

The various financial institutions, including banks, insurance companies, institutional investors, are closely related. The banks get close to the operators of the financial life via the various payment systems, and therefore if a bank has liquidity problems and subsequently becomes insolvent (on a long term) then it will affect all institutions being in connection with it. This is called an infection effect when the problem causes a severe crisis in the whole financial system, which means that much more stringent rules should be applicable to the financial institutions than to traditional businesses.

We would believe that the necessity of banking regulation is clear, however, even economic specialists do not agree in this matter. Many refer to the significant costs of state interventions which are financed from the taxpayers' money in the case of a 
bankruptcy. At the same time, on the basis of so-called free banking, banks should operate on the basis of the regulatory mechanism of market, as in the case of other business, which would result in mush less costs.

"Free banking is, in fact, a limited presence or even lack of banking regulation; money creation, more closely its regulation or non-regulation is decisive within regulation. This approach questions the necessity of central banks and is based on absolutely proper decisions of the banks, the full applicability of the laisser-faire principle." (Zsolnai, 2012)

In our opinion, the managers of the financial institutions are fully aware of the extent of the risks assumed by them. They know that keeping of the confidence of depositors is the most important task, and therefore they spend much on protection against the occurrence of unfavourable events.

The Union's banking regulation contains guidelines and regulations. The member states have to transpose the guidelines into their national legal framework, while the regulations are mandatory for all countries.

The banking regulation within the Union has been divided into two parts until now:

- the regulatory level of the national authorities which regulates the operation of the financial institutions in accordance with the national specificities in all countries, and

- the directives of the European Union, which are mandatory but are transposed by the countries into their own legal framework in accordance with the national specificities.

The Single Rulebook is intended to change this division by providing uniform rules in each member states by means of regulations and standards issued by the European Banking Authority (EBA).

The Single Rulebook sets capital requirements for the banks, provides a higher level of protection for depositors, and helps to prevent bankruptcy situations and to manage bankrupted banks.

Regulation related to the banks can be divided basically into two groups:

State regulation covers deposit insurance and the function of the central banks as a lender of last resort to commercial banks. More closely, the purpose of deposit insurance is to protect the depositors, to ensure confidence in banks and thereby to protect the financial stability of the country.

The central bank's function as a lender of last resort (LoLR) means that the central bank may grant credits to insolvent banks. This entails the problem of a moral risk, which is that larger banks dare undertake risky transactions as they are sure that the central bank will help them. Therefore the banks must meet various conditions to be able to receive such credits, for example only illiquid banks may receive last resort financial assistance, the price of which is higher than the market price. It is important to note that in the case of a bankruptcy, in addition to the costs of the state's role the costs of losing the confidence of clients are also high and appear on a long term. Regaining the confidence of depositors needs much time and effort.

The prudential regulationis the other group. It is intended to enable the bank to keep its long term solvency.

Mishkin distinguishes eight types of prudential regulation (Erdős et al. 2010): 
- restrictions on maintaining assets and activities,

- separation of banking from other financial activities,

- competitive constraints,

- capital rules,

- risk-based pricing of deposit insurance,

- requirements of publication,

- requirements of authorisation,

- continuous control of compliance with the regulatory requirements.

In the recent years, most of the rules have become less significant due to the liberalisation of the financial markets, globalisation, the free capital flow within the European Union. By now, the geographic limitation of opening of a bank has been terminated, resulting in a much less transparent system. The regulation tends to move from risk base regulation to rule base regulation in the whole world, and is supplemented with the regulation of system risks. This will rearrange the relations between the states and banks, the European Central Bank and other Union institutions as well as the member states of the euro zone and non-euro zone Union countries.

\section{Micro- and Macroprudential Regulation, System Risk in the Banking sector}

The necessity of micro- and mainly macroprudential regulation has an increasing priority at international level. The first is intended to protect the depositors and to reduce the probability of occurrence of bankruptcies. While the macroprudential regulation is intended to minimise large scale system level risks. The characteristics of these two types of regulation are summarised in the first table.

Table 1: Characteristics of Micro- and Macroprudential Regulation

\begin{tabular}{|l|l|l|}
\hline Designation & \multicolumn{1}{|c|}{$\begin{array}{c}\text { Characteristics of } \\
\text { microprudential regulation }\end{array}$} & \multicolumn{1}{c|}{$\begin{array}{c}\text { Characteristics of } \\
\text { macroprudential regulation }\end{array}$} \\
\hline $\begin{array}{l}\text { Purpose of } \\
\text { regulation }\end{array}$ & $\begin{array}{l}\text { reduction of the probability of } \\
\text { individual bankruptcy }\end{array}$ & $\begin{array}{l}\text { reduction of the system risk, } \\
\text { minimisation of the resulting costs }\end{array}$ \\
\hline Focus & individual institutions & $\begin{array}{l}\text { the whole bank system due to the } \\
\text { correlating risks }\end{array}$ \\
\hline $\begin{array}{l}\text { Ideology of } \\
\text { regulation }\end{array}$ & $\begin{array}{l}\text { the system remains stable as long } \\
\text { as all individual institutions well } \\
\text { function }\end{array}$ & $\begin{array}{l}\text { the problem is not the bankruptcy } \\
\text { of one institution }\end{array}$ \\
\hline $\begin{array}{l}\text { Principle of } \\
\text { regulation }\end{array}$ & $\begin{array}{l}\text { bottom-up: requirements set for a } \\
\text { representative institution are valid } \\
\text { for everyone }\end{array}$ & $\begin{array}{l}\text { top-down: it departs from the } \\
\text { probability of the occurrence of a } \\
\text { crisis }\end{array}$ \\
\hline $\begin{array}{l}\text { Method of } \\
\text { regulation }\end{array}$ & uniform standards & $\begin{array}{l}\text { individual rules depending on the } \\
\text { economic weight of the institutions }\end{array}$ \\
\hline $\begin{array}{l}\text { Idea about } \\
\text { economy }\end{array}$ & $\begin{array}{l}\text { exogeneous variables: they are } \\
\text { specific for the individual } \\
\text { institutions }\end{array}$ & $\begin{array}{l}\text { endogeneous variables: the result of } \\
\text { the joint behaviour of the individual } \\
\text { institutions }\end{array}$ \\
\hline
\end{tabular}

Source: Lublóy (2003) p. 74 
Kenesey, Zs. - Nagyné Sasvári, M. - Pataki, L. - Ambrus, R. A.

The attention to the lack of the macroprudential regulation of banks was called by the financial crisis. In the narrow sense, system risk means that a specific event affecting first only a narrow part of the economy adversely influences also other economic fields after a while. In its broadest sense, the event has a severe effect on several institutions and markets. The event is weak if no institution goes bankrupt as a result of the shock. It is strong if even only one institution goes bankrupt, which could not have happened without the shock (Lublóy, 2003).

There are two types of risks in the case of banks. The individual risks affect only the bank concerned, while the system level risk has an influence on the financial system as a whole and thereby also on the whole economy. Such economic operators are called Systematically Important Financial Institution (SIFI).

Today, new terms appear in connection with this topic. The principle of "too big to fail" is replaced by the principle of "too big to save" to an increasing extent, that is the most giant banks are now too big to save. Banking regulation has moved into this direction. The economic capacities of the countries do not allow them to allocate enormous amounts to the saving of financial institutions and thereby to risk the stability of the country.

Figure 1 shows the 10 global systemically important banks (GSIB) having the largest assets. Based on the report of November 2014 of the Financial Stability Board, 31 such banks operate currently in the world.

Figure 1: The Greatest Banks of the World (2014)

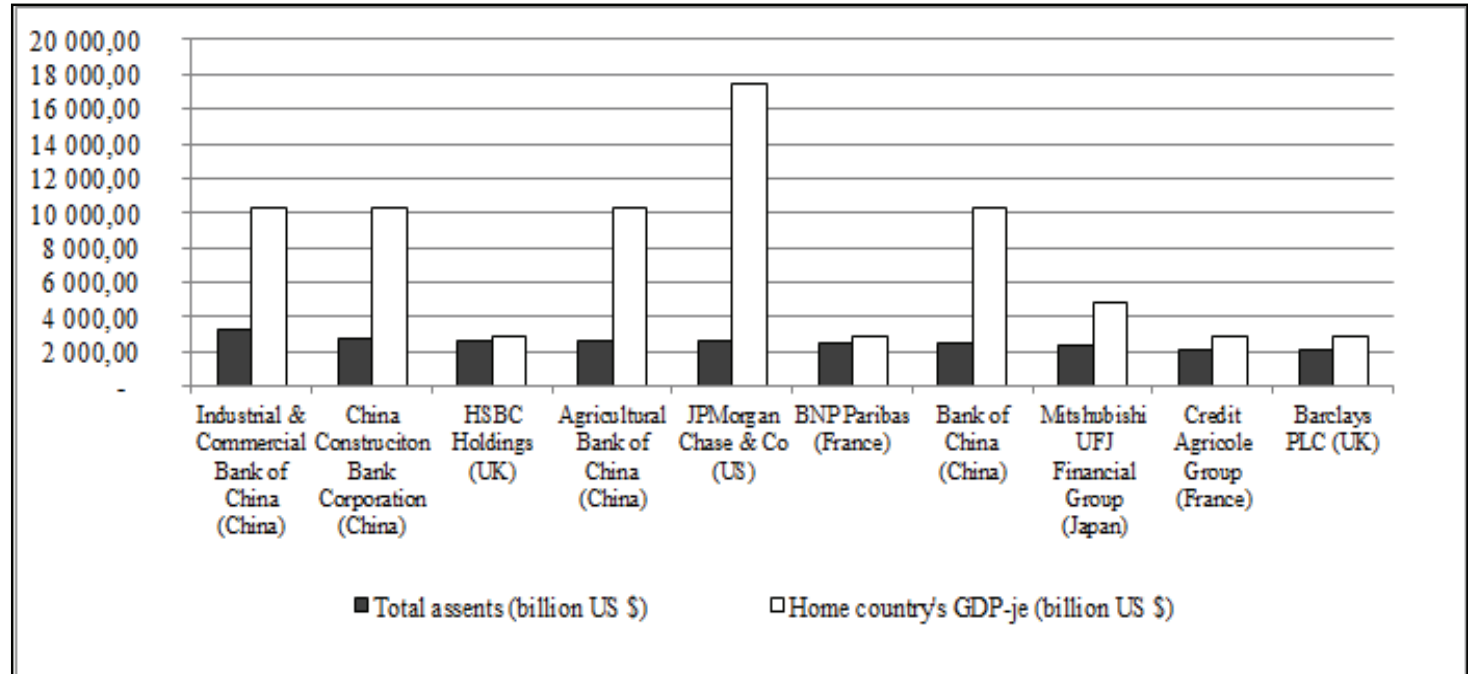

Source: own edition on the basis of the data of the websites of the Realbank and Economy Watch

There are four Chinese banks and one Japanese bank among the first 10 ones. The first ICBC was only the $32^{\text {nd }}$ on the list in 2004, and was already among the 10 best ones from 2006, and became the first one from 2013. Though the seat of the third largest HSBC Holdings is in the United Kingdom, most of its incomes come from the Asian 
market. JP Morgan Chase is the largest bank in the United States. In addition to them, the top ten include the French BNP Paribas, Credit Agricole and the English Barclays. Compared to their GDPs of the countries, the European banking system is larger than the American one. The balance sheet totals of the large European banks are not high compared to the European GDP, but are enormous compared to the national incomes of their own countries.

The figure well illustrates that the GDPs of Chine, US and Japan are enormous, and the balance sheet totals of the banks are insignificant compared to these values. However, the difference between the assets of the largest European banks and the GDPs of their home countries is not so significant at all.

Figure 2 contains data for 2014, based on which the English HSBC Holdings was the greatest bank in Europe. The $8^{\text {th }}$ largest bank, Banco Santander had assets exceeding the GDP of Spain.

Among the 10 largest European banks, 4 are located in the United Kingdom, 4 in France, one in Germany and one in Spain. In 2014, the balance sheet totals of all banks exceeded $50 \%$ of the GDPs of the countries where they had their seats, and 7 banks had assets exceeding $10 \%$ of the GDP of the EU. It is still not clear for the decision makers of the EU what will happen to those TBTF banks that are two big to save. The separation of the classical and commercial activities of the banks has been recommended to solve this problem, on which discussions are being held.

Figure 2: TBTF Banks in Europe (2014)

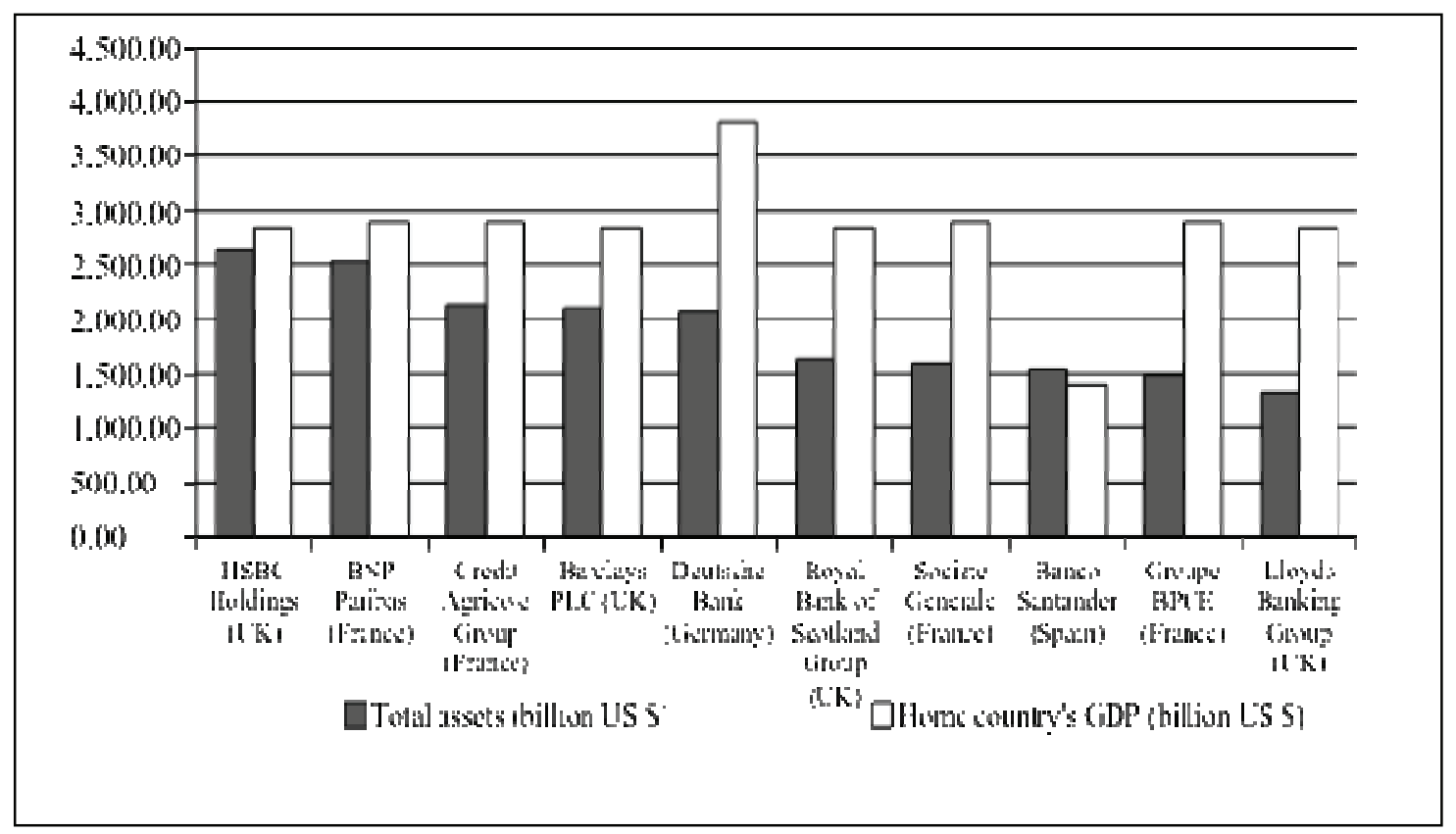

Source: own edition

on the basis of the data of the websites of the Realbank and Economy Watch 


\section{Basel Bank Rules (Basel I, Basel II, Basel III)}

The internationalisation process of the banks started in the second half of the $20^{\text {th }}$ century. Due to the accelerated globalisation and integration, establishment of uniform regulation has become necessary in the banking sector. In 1974, the Basel Committee on Banking Supervision (BCSB) was created with the involvement of 13 countries, which has an advisory role, and its recommendations may be adopted and applied by the member states and other countries.

The Based Accord established in 1988 is the most important measure of the Committee, which specified a minimum capital level for the banks. They specified the definition of solvency margin, which represents the bank's equity and the resources which may be included in the settlement of payables by the credit institution as a capital.

The principle of operation of the credit institutions is that they must continuously maintain their liquidity and solvency. The solvency rate is intended to guarantee the solvent operation of the bank, and its current value is 8 , which means that the solvency margin must be higher than $8 \%$ of the risk-weighted assets.

The Accord has been criticised from several aspects, for example because identical risks weights were valid for companies listed in the stock exchange and for family businesses. Several supplementations were attached to Basel I, but they were not sufficiently effective.

Basel II was created in its final form in 2006. It laid a greater emphasis on the risk management processes, was more flexible, and took into consideration also the operational risks in addition to the market risks. It required the maintenance of capital reserve sufficient to cover the expected risks. It emphasised that the solvency margin was to be considered the difference between the available and the necessary capitals. The Accord was well accepted. Almost simultaneously with Basel II, rules relating to capital requirements known as the Capital Requirement Directive for Credit Institutions and Investment Firms (CRD) were created. While the first was a proposal applicable only to internationally active banks, the CRD is mandatory for all credit institutions and investment businesses operating in the Union.

In 2013, CRD IV Directive and CRR Regulation adopted by the European Parliament jointly replaced the CRD directives containing capital requirement regulation of the credit institutions and investment businesses. The CRR Regulation and the modification of the CRD IV Directive came into effect as of 1 January 2014. The regulation is mandatory for the Union countries, while the directive is to be only transposed into their legal framework. The tightening of the solvency margin capital requirements is a new element, which was required due to the crisis in 2008, since previously risky elements were also included in the capital resulting in its dilution, and therefore the financial institutions had to create also anticyclical and capital maintenance reserves. From 2015, the banks must publish their data (Kiss, 2014).

Basel III was published in 2009 and finalised in September 2010, which contains significant changes, in particular, in the solvency margin elements. All G20 countries recognise it as binding, i.e. it is created as a global standard (Szombati, 2012). The 
regulation introduces the term of leverage ratio which is the ratio of the common equity and all exposures. The specified value is 3\%, which must be reached from 2018. The Basel Committee on Banking Supervision has worked out quality and quantity indexes to qualify the global systematically important banks (GSIBs). These banks were classified into five groups on the basis of their systemic risk effects, and surplus capital requirements were assigned to the individual categories $(2.5 \%$ as the highest $)$ the adherence to which gradually becomes compulsory between 2016 and 2019 (Mérö, 2011).

The introduction of new indexes is the greatest change, since the previous Basel directives did not contain requirements for the liquidity levels of the banks.

In accordance with the first proposal, the banks have to possess liquid financial assets for at least 30 days. The LCR (liquidity coverage ratio) is an index necessary for its calculation. It was introduced in 2015 , which means that $60 \%$ of the assets of the banks have to be liquid assets good enough to be involved in crisis management for 30 days. This value has to be increased by $10 \%$ per year in order to reach $100 \%$ by 2019 . In accordance with the second proposal, the bank's balance structure must allow independent operation on a long term, i.e. the permanent sources must exceed the rate of liquid sources. It is calculated with the NSFR (net stable funding ratio) index, and it is planned to be introduced in 2018.

\section{New Regulatory Framework: the European Bank Union}

The bank union is part of an integrated financial framework, and is also a response to the financial and economic crisis, which was specified when it became clear that an intensive reform was needed to eliminate the regulatory and supervisory deficiencies. The bank union is based on three pillars:

- Single Supervisory Mechanism (SSM),

- Single Resolution Mechanism (SRM),

- Deposit Guarantee Scheme (DGS).

Adherence to the capital requirements related to banks (CRD IV) and to the directive on the recovery and resolution of banks is added to the three pillars.

The single supervisory mechanism (SSM) considered the first pillar of the bank union was assigned to the scope of the European Central Bank form 1 November 2014. It means, in fact, the supervision over commercial banks belonging to the euro zone is assigned to the scope of the ECB. This means currently 124 banks and more than $80 \%$ of the assets. Banks managing financial assets above 30 billion euro or having assets above $20 \%$ of their country's GDP are under control.

Based the Union's stress test made in October 2014, OTP Bank meets this condition in Hungary. In 2014, 76\% of the bank deposits available in the European Union were owned by banks seated in the euro zone, and this is one of the reasons a more intensive supervision is reasonable (EBF, 2014,).

The second pillar, the single resolution mechanism means, in fact, that banks close to bankruptcy are not saved from the money of taxpayers, but the responsibility must be assumed by their shareholders and creditors. The single resolution panel on which the 
single resolution mechanism (SRM) is based started to operate in Brussels on 1 January 2015. In all Union countries, national resolutions funds have to be created, and from January 2016, these will be replaced with a single restoration fund, and from that time the banks will pay $1 \%$ of the secured deposits into it. The estimated amount of the paid contributions will be EUR 55 billion by the end of the period, i.e. 2022, or even higher if non-euro zone countries also join meanwhile.

The deposit guarantee scheme (DGS) is an important element of the bank union, since with its rules it may contribute to the restoration of the confidence of depositors in the financial institutions. In April 2014, the latest decision on the regulation of the third pillar was made, which must be transposed by the member states into their practice by 3 July 2015. It is a new element that the credit institutions must pay a fee on deposits subject to compensation obligation by 31 December preceding the subject year.

Bonds and deposit certificates issued by the credit institutions are removed from elements protected by deposit guarantors, but from now a compensation limit of EUR 100,000 is applicable to community deposits, and local governments with budgets less than EUR 500,000 are protected by deposit guarantors. Now, 20 banking days are available for payments, but in accordance with the Union's requirements, this period must be gradually limited to 7 banking days until 2024 .

Currently 19 euro zone countries are members of the bank union. The remaining 9 countries have different opinions on joining. Since the idea of the single supervision, Great Britain has been emphasising that they do not want to expose their banks to control by the ECB due to its special situation in the financial sector. Sweden has a similar viewpoint. 3 Union countries, Denmark, Romania and Bulgaria are for joining, but have not yet indicated their intention. Our country, the Czech Republic, Poland and Croatia joining in 2015 are currently waiting.

In accordance with the study made by the National Bank of Hungary in 2014, the crisis management fund of EUR 55 billion is a definite advantage of joining, which may contribute to the financing of bank bailouts. Belonging to a larger risk community, precise knowledge of the rules and involvement in decision making are all arguments for joining the bank union.

Due to power modification, a new entry wave and thereby an increased market pressure, our country may decide to join earlier than it planned to do so. At the same time, there are several error possibilities in the system, new elements may be introduced after a while, and therefore our country is still monitoring the events from the background. 
Figure 3: The Relations of the EU Member States with the Bank Union

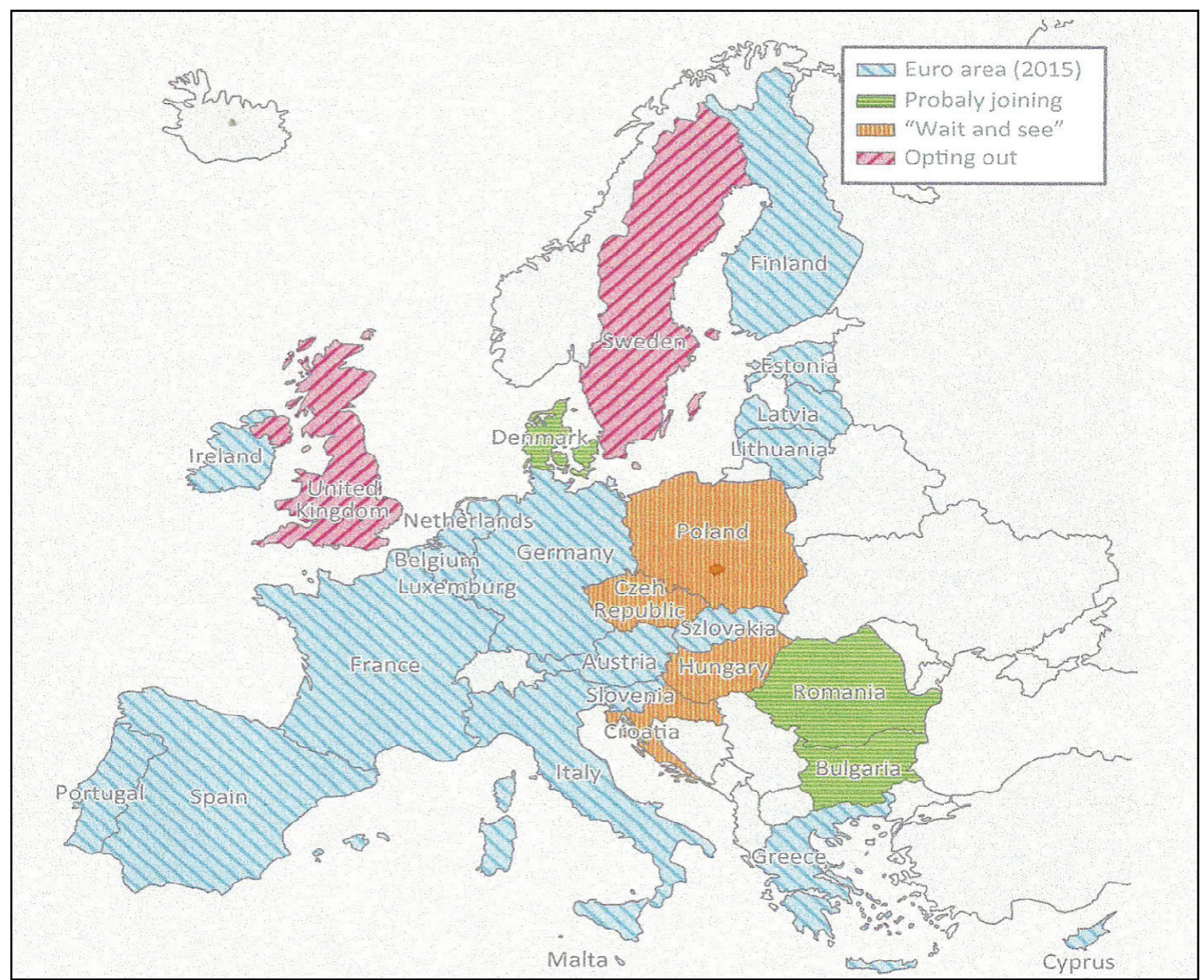

Source: National Bank of Hungary (2014)

The formation of the system has been preceded by a long process, as nearly 8 years have passed since the crisis. The bank union will surely be in the focus of discussions between the decision-makers for a long time, as certain rules will be introduced with periods of grace, and the EU countries will gradually join, i.e. the final formation of the bank union will last for several years. Though none of the countries wants it, but the operability of the system could possibly be evaluated and really studied in another crisis.

\section{Conclusions}

The quantitative regulation characteristic of the 1970s has been replaced with risk based approaches by now, i.e. the economic importance of the banks depends not only on the volume of deposits but also on the risks entailed by them.

Safe operation of the banks is in the interest of all operators of economy. Prudent operation is important due to the increase of deposits primarily from the aspect of the 
inhabitants, which finally affects consumption, production and ultimately the economy as a whole.

The major problem with state assistance is that they use the money of taxpayers to bail out banks instead of spending money on the creation of proper protection systems and using the money first of all of shareholders and creditors to solve the problem. Today, large banks expect the state to bail them out, and therefore they are inclined to invest the savings of people in assets involving high risks. This way of thinking endangers the operation on the economy. The crisis of 2008 has called the attention to the deficiencies in the banking regulation and to the resulting problems. Due to the complexity of connections and to the risk of any negative consequence's becoming an international one, it is difficult but indispensible to find a proper solution which may result even in additional expansion of banking regulation at international level.

\section{References}

1. Economy Watch (2014): Economic Statistics by Country http://www.economywatch.com/economic-statistics/economicindicators/GDP Current Prices US Dollars/Date of downloading: 15 April 2015

2. European Banking Federation EBF (2014): European Banking Sector Facts \& Figures http://www.ebf-fbe.eu/publications/statistics/ Date of downloading: 3 April 2015

3. Erdős M., Mérő K. (2010): Pénzügyi közvetítő intézmények. Akadémiai Kiadó, Budapest, $292 \mathrm{p}$.

4. Financial Stability Board (2014): 2014 update of list of global systemically important banks (G-SIBs) http://www.financialstabilityboard.org/2014/11/2014update-of-list-of-global-systemically-important-banks/ Date of downloading: 2 April 2015

5. Kiss A. (2014): A Bázel III. és az Európai Unió http://www.corvinusembassy.com/ep/?page=2\&article=2\&show=135 Date of downloading: 15 April 2015

6. Kisgergely K., Szombati A. (2014): Bankunió Magyar szemmel - hogyan látja az MNB a szoros együttmüködés lehetőségét? MNB tanulmányok 115. http://english.mnb.hu/Root/Dokumentumtar/ENMNB/Kiadvanyok/mnben muhely tanulmanyok/Banking_Union_MNB_OP 115.pdf Date of downloading: 12 April 2015

7. Lublóy Á. (2003): Rendszerkockázat a bankszektorban. Hitelintézeti Szemle 2003. 2. évf. 4. számpp 69-90. http://www.bankszovetseg.hu/wpcontent/uploads/2012/10/034Lubloy.pdf Date of downloading: 22 March 2015

8. Mérö K. (2012): Egy paradigm születése és bukása A „túl nagy a csődhöz” elv értelmezésének és alkalmazásának változásai http://econ.core.hu/file/download/vesz2012/tulnagyacsodhoz.pdf Date of downloading: 5 March 2015

9. Realbank website: World's largest banks 2014, http://www.relbanks.com/worldstop-banks/assets Date of downloading: 15 April 2015 
10. Szombati A. (2010): Bázel III rendszerszintű hatásai itthon és Európában. MNB Szemle,http://www.mnb.hu/Root/Dokumentumtar/MNB/Kiadvanyok/mnbhu_mnb szemle/mnbhu_msz_201012/szombati.pdf Date of downloading: 5 March $20 \overline{15}$

11. Zsolnai A. (2012): A banki tőkekövetelményi szabályozás jellegzetességei, háttere és nehézségei,

http://www.asz.hu/penzugyi-szemle-cikkek/2012/a-banki-tokekovetelmenyiszabalyozas-jellegzetessegei-hattere-es-nehezsegei/213-225-zsolnaia.pdf Date of downloading: 8 April 2015 